simples separados com fio de vicryl 5-0. Após término da amputação do prolapso foi realizada orquiectomia por técnica rotineira. No período pós-operatório o animal recebeu enrofloxacina na dose de $5 \mathrm{mg} / \mathrm{Kg}$ as cada 12 horas por 10 dias e predinisolona na dose de $1 \mathrm{mg} / \mathrm{Kg}$ a cada 24 horas durante cinco dias e mantido com colar elizabetano por 30 dias. Após 30 dias de pós operatório o animal encontrava-se em ótimo estado geral, não sendo mais observado sangramento.

\title{
16 - Cirurgia de palato mole alongado em cães (estafilectomia)
}

Leon Roman, M.A.';

Hofmann F. ${ }^{2}$; Gioso, M. A. ${ }^{3}$

\author{
1- Médico Veterinário autônomo - Odontovet, São Paulo-SP \\ 2- Médico Veterinário autônomo - Odontovet, São Paulo-SP \\ 3- Departamento de Cirurgia da Faculdade de Medicina Veterinária e Zootecnia da Universidade de São \\ Paulo, São Paulo-SP
}

Palato mole alongado em cães é um problema pouco diagnosticado na prática veterinária, podendo ocorrer em qualquer raça. Os sinais clínicos dependem do grau de estenose na faringe e incluem vômito, dificuldade de deglutição, ruídos respiratórios e, ocasionalmente, dispnéia. Casos severos podem incluir complicações maiores, como dispnéia, cianose, colapso de laringe e síncope, principalmente em braquicefálicos, por apresentarem anormalidades na estrutura nasolaríngea, assim como estreitamento das vias aéreas, edema dos tubérculos cuneiforme e corniculato da aritenóide, e eversão dos ventrículos laterais, aumentando assim, a resistência do ar na respiração. Durante a inspiração, a porção alongada do palato mole pode obstruir a laringe, interferindo na entrada de ar pela traquéia, resultando em processo inflamatório e edema na região, devido ao permanente contato entre as estruturas. Estes sinais acentuam-se principalmente durante o estresse, cansaço, no aumento da atividade física e em temperaturas elevadas. O diagnóstico é realizado através de exame físico, observando-se a relação entre o palato mole e o espaço existente na faringe, através de laringoscópio ou endoscopia. O palato mole deve apenas tocar a extremidade da epiglote ou se estender até a porção caudal ou média da tonsila, evidenciando a laringe. Entretanto, esta relação pode ser modificada quando não houver um correto posicionamento da cabeça $\mathrm{e}$ do pescoço, bem como da mandỉbula. A correção é realizada mediante procedimento cirúrgico, devendo o animal permanecer em decúbito esternal e a cavidade oral aberta a fim de melhor evidenciar o local de acesso. No trans-operatório faz-se necessário o uso de corticóides, na tentativa de minimizar o edema na região. Através de uma pinça de Allis, o alongamento do palato mole é forçado a voltar para sua posição normal. Em cada extremidade da porção alongada do palato é colocado um ponto de apoio para orientar a linha de incisão, que é realizada com uma lâmina de bisturi número 15 ou laser de alta potência. Para a sutura, utiliza-se fio absorvível à base de poliglactina 910 (Vicryl). Quando a ressecção ultrapassa o limite máximo, pode haver aspiração nasal de líquidos e alimentos, resultando em rinite e pneumonia. No período pós-operatório imediato, alguns sinais como vômito, ruídos respiratórios, e o engasgar são comuns. Durante as primeiras $24-48$ horas os reflexos faríngeos freqüentemente não funcionam normalmente e a aspiração ou obstrução nasal podem acontecer. Por isso, é importante identificar o problema cedo e instituir uma nova terapia imediatamente. De acordo com a literatura, pacientes com menos de 2 anos apresentam melhor prognóstico do que animais acima desta idade. Foi atendido no Laboratório de Odontologia Comparada , LOC-FMVZ/USP, um Poodle, 5 anos, fêmea, apresentando dificuldade respiratória, dispnéia, tosse e sons ruidosos na inspiração. O paciente foi submetido à anestesia geral inalatória, tendo sido pré-medicado com acepromazina $0,2 \%(0,1 \mathrm{mg} / \mathrm{kg})$, meperidina $(2 \mathrm{mg} / \mathrm{kg})$ e induzido com propofol $(5 \mathrm{mg} / \mathrm{kg})$, foi mantido em plano anestésico com isoflurano, para então realizar-se a estafilectomia. $\mathrm{O}$ animal apresentou boa recuperação pós-operatória e os sinais clínicos iniciais desapareceram por completo, $\mathrm{e}$ assim perduram há vários meses. 